\title{
JURNAL
}

TEKNOLOGI INFORMASI

\section{Rancang bangun Sistem Informasi Kerjasama Universitas Kristen Satya Wacana}

Fredrik Landjamara Ndjurumana ${ }^{1)}$, Evangs Mailoa ${ }^{1)}$

Program Studi Teknik Informatika Fakultas Teknologi Informasi

Universitas Kristen Satya Wacana

Jl. O. Notohamidjojo

Email : fredrik.ndjurumana@uksw.edu

\begin{tabular}{|c|c|c|}
\hline Recieved: 01-12-2020 & $\begin{array}{c}\text { Riwayat artikel: } \\
\text { Revised: 06-02-2020 }\end{array}$ & Accepted: 06-02-2020 \\
\hline
\end{tabular}

\section{Abstract}

In order to improve institutional capabilities, UKSW needs to collaborate with various parties. Documents of agreement which is the references of implementation must be archived and managed properly. The document of agreement in UKSW, still manage manually, making it difficult to find complete data related to the cooperation agreement that has been made by UKSW. Information technology has an important role in increasing the efficiency and effectiveness of the document management and archiving. This study aims to develop a cooperation information system that capable to record the whole process of submitting agreement, until the process of archiving the signed document. Rapid Application Development (RAD) method used with the aim of accelerating development process, providing good quality of system, and reducing development and maintenance costs. The result of this research is a cooperation information system that has been implemented at UKSW Salatiga.

Keywords: cooperation, filing, RAD

\begin{abstract}
Abstrak
Kerjasama dengan berbagai pihak sangat diperlukan oleh UKSW untuk dapat meningkatkan kapabilitas kelembagaan dalam mewujudkan visi dan misinya. Kesepakatan yang dituangkan dalam dokumen perjanjian kerjasama yang menjadi dasar implementasi kerjasama harus diarsipkan dan dikelola dengan baik. Pengelolaan arsip dikumen kerjasama di UKSW masih dilakukan secara manual, sehingga menyulitkan dalam pencarian untuk memperoleh data yang lengkap terkait perjanjian kerjasama yang telah dilakukan UKSW. Pemanfaatan teknologi informasi menjadi sangat penting untuk mengelola pengarsipan dokumen perjanjian kerjasama. Penelitian ini bertujuan untuk mengembangkan sebuah sistem informasi kerjasama yang mampu merekam proses pengusulan suatu perjanjian kerjasama hingga pada proses pengarsipan dokumen perjanjian kerjasama. Metode pengembangan sistem menggunakan Rapid Application Development (RAD) dengan tujuan untuk mempercepat proses pengembangan, memberikan kualitas sistem yang baik, serta menekan biaya pengembangan dan pemeliharaan. Hasil yang diperoleh dari penelitian ini berupa sebuah sistem informasi kerjasama yang telah diterapkan di UKSW Salatiga.
\end{abstract}

Kata kunci: kerjasama, pengarsipan, RAD 


\section{Pendahuluan}

Universitas Kristen Satya Wacana sebagai sebuah instutusi pendidikan, dalam perkembangannya tidak dapat berdiri sendiri. Untuk menjaga kelangsungan hidupnya, UKSW perlu menjalin kerjasama dengan berbagai pihak. Kerjasama dilakukan dengan tujuan untuk mendapatkan nilai tambah bagi UKSW, yang berguna untuk meningkatkan kapabilitas UKSW sebagai sebuah institusi pendidikan tinggi[1]. Pelaksanaan kerjasama dilakukan dengan memperhatikan kesamaan visi yang ingin dicapai oleh UKSW dengan pihak-pihak yang bekerjasama.

Kesepakatan kerjasama yang dilakukan dituangkan dalam bentuk dokumen perjanjian kerjasama. Keberadaan dokumen ini menjadi sangat penting karena berisi butir-butir kesepakatan antara UKSW dengan pihak yang menjalin kerja sama. Dokumen perjanjian kerjasama harus diarsipkan sehingga dapat digunakan kembali jika diperlukan di kemudian hari. Untuk itu diperlukan suatu sistem pengelolaan dan pengarsipan dokumen kerja sama yang baik. Seiring dengan perkembangan teknologi informasi, pengarsipan dokumen dilakukan dengan mengkombinasikan antara pengarsipan secara fisik dan digital atau berbasis komputer. Saat ini, telah banyak institusi yang menerapkan sistem pengarsipan secara digital dalam mengelola arsip dokumen yang dimilikinya[2]. Salah satu metode pengarsipan dokumen secara digital adalah dengan menggunakan sistem informasi yang secara khusus dibuat untuk mengelola arsip dokumen.

Sebagian besar dari kegiatan administratif yang dilakukan dalam sebuah institusi adalah pengelolaan arsip dokumen untuk menunjang proses bisnis institusi tersebut[3]. Sama seperti pengelolaan arsip dokumen pada umumnya, pengelolaan arsip kerjasama di UKSW masih dilakukan secara manual. Sistem ini memiliki kelemahan, terutama proses pencarian yang membutuhkan waktu yang lebih lama. Dengan jumlah dokumen yang semakin banyak, sistem manual semakin mempersulit proses pelacakan terhadap kerja sama yang akan atau telah berakhir masa berlakunya[4]. Dirangkum dari situs Sistem Laporan Kerja Sama Kementerian Pendidikan dan Kebudayaan, terdapat 489 dokumen kerjasama UKSW yang dilaporkan dalam periode tahun 2018 hingga tahun 2020. Jika ditelusuri lebih jauh, terdapat perjanjian kerja sama yang dimiliki UKSW namun belum dilaporkan atau tidak terarsip dengan baik dalam jumlah yang cukup besar. Solusi yang ditawarkan untuk mengatasi permasalahan di UKSW ini adalah dengan membangun sebuah sistem informasi kerjasama, yang memiliki fungsi utama untuk mengarsipkan dokumen-dokumen kerjasama serta mengelola usulan-usulan kerjasama baru yang diajukan oleh Fakultas/Biro di UKSW.

\section{Kajian Pustaka}

Permendikbud Nomor 14 Tahun 2014 menyatakan bahwa kerjasama yang dilakukan oleh Perguruan Tinggi, bertujuan untuk meningkatkan efektivitas, efisiensi, produktivitas, kreativitas, inovasi, mutu dan relevansi pelaksanaan Tri 
Darma Perguruan Tinggi[5]. Oleh karena itu, Perguruan Tinggi diberikan ruang untuk melakukan kerjasama dalam bidang akademik maupun non akademik dengan perguruan tinggi lain, dunia usaha atau pihak lain baik dari dalam negeri maupun luar negeri.

Perjanjian kerjasama yang telah ditandatangani semua pihak, disimpan sebagai arsip dan dikelola oleh masing-masing institusi yang melakukan kerjasama. Arsip dapat diartikan sebagai catatan yang tertulis, tercetak, atau ketikan dalam bentuk huruf, angka atau gambar yang mempunyai arti dan tujuan tertentu sebagai bahan komunikasi dan informasi, yang terekam dalam kertas (kartu, formulir), kertas film (slide, film-strip, mikro-film), media komputer (pita, piringan, rekaman, disket), kertas photocopy dan lain sebagainya [6].

Suatu sistem pengarsipan elektronik, harus memenuhi beberapa aspek yaitu kesederhanaan dalam pengoperasian, kemudahan dalam akses, kapasitas penyimpanan yang memadai serta keamanan sistem yang baik[7]. Mengacu pada penelitian yang dilakukan Sugiarto dkk, sistem informasi kerjasama dibangun dengan mempertimbangkan aspek-aspek tersebut. Sistem ini dirancang untuk dapat diakses melalui jaringan intranet dan internet, dengan desain antarmuka dan prosedur yang mudah dipahami oleh user.

Dalam penelitian yang dilakukan oleh Rusdiansyah, pengolahan surat perjanjian kerjasama dapat dilakukan dari mana saja melalui jaringan internet. Penelitian ini juga menghasilkan sebuah sistem pengarsipan surat perjanjian kerjasama yang dapat dijalankan secara multi user[8]. Akan tetapi, pengaturan hak akses bagi setiap user, hanya dibagi ke dalam 2 kelompok yaitu admin dan operator. Selain itu, sistem yang dibangun hanya untuk mengarsipkan surat perjanjian kerjasama. Berbeda dari penelitian sebelumnya, sistem yang dikembangkan ini menyediakan pembagian hak akses dalam beberapa level yaitu administrator yang memiliki hak akses secara penuh, pengusul yang diberikan hak untuk mengajukan usulan kerjasama, validator yang memiliki kewenangan untuk memproses usulan kerjasama dari setiap unit, reviewer yang melakukan penelaahan naskah perjanjian kerjasama. Terdapat juga hak akses montoring and evaluation untuk melakukan pengawasan dan evaluasi terhadap perjanjian kerjasama yang sedang berjalan.

Penelitian yang dilakukan oleh Sugianto dan Aulia, menghasilkan sebuah sistem informasi kerjasama yang memiliki fitur Admin dan Mitra[9]. Sistem informasi kerjasama yang dihasilkan memiliki fitur antara lain pendaftaran mitra dan diskusi kerjasama. Sejalan dengan penelitian tersebut, sistem informasi kerjasama yang dikembangkan ini menyediakan fitur komentar pada setiap tahapan. Fitur ini dimaksudkan agar setiap user yang terlibat dalam pengusulan kerjasama dapat mengetahui masukan-masukan ataupun catatan yang diberikan oleh validator maupun reviewer. Fitur lain yang juga ditambahkan adalah riwayat usulan, yang 
AITI: Jurnal Teknologi Informasi

bertujuan agar pengguna dapat mengetahui tahapan yang telah dicapai dalam proses usulan kerjasama.

\section{Metode Penelitian}

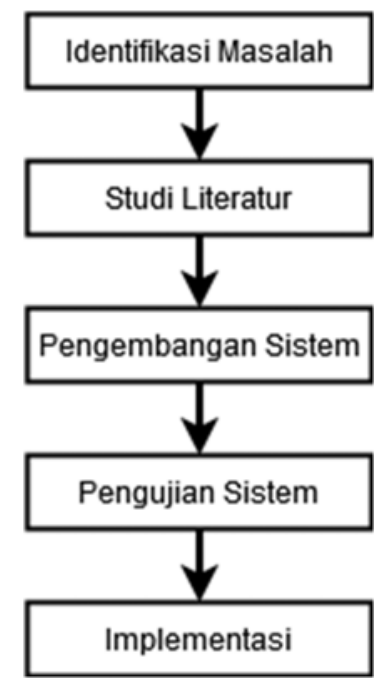

Gambar 1 Tahapan Penelitian

Gambar 1 menunjukkan tahapan yang dilakukan dalam penelitian ini. Identifikasi masalah dilakukan dengan cara penelusuran terhadap masalah-masalah yang dihadapi di tempat penelitian. Studi literatur dilakukan untuk mendapatkan sumber-sumber pustaka yang relevan berdasarkan masalah yang telah diidentifikasi, yang meliputi kajian terhadap penelitian-penelitian terdahulu yang terkait untuk mendapatkan teori-teori yang mendukung penelitian ini, termasuk kajian terhadap dokumen-dokumen yang digunakan sebagai pedoman pelaksanaan kerjasama perguruan tinggi.

Pengembangan sistem dilakukan dengan menerapkan model pengembangan perangkat lunak Rapid Application Development (RAD). Model RAD merupakan kumpulan metode yang dikembangkan untuk mengatasi kelemahan dari metode tradisional dalam pengembangan sistem seperti model Waterfall dan beberapa model lainnya[10]. Pemilihan model RAD dalam penelitian ini mempertimbangkan keunggulan yang dimiliki model RAD jika dibandingkan dengan model pengembangan software lainnya. Keunggulan model ini adalah memungkinkan siklus pengembangan sistem secara cepat, kualitas sistem yang lebih baik dibandingkan model pengembangan perangkat lunak tradisional, serta biaya pengembangan dan pemeliharaan sistem yang lebih rendah.

Sistem Informasi Kerjasama UKSW dikembangkan mengacu pada SOP Usulan Kerjasama yang berlaku di UKSW yaitu . SOP usulan kerjasama dibedakan ke dalam 2 jenis yaitu SOP Usulan Perjanjian Kerjasama (Memorandum of Agreement) dan SOP Usulan Memorandum of Understanding (MoU). 


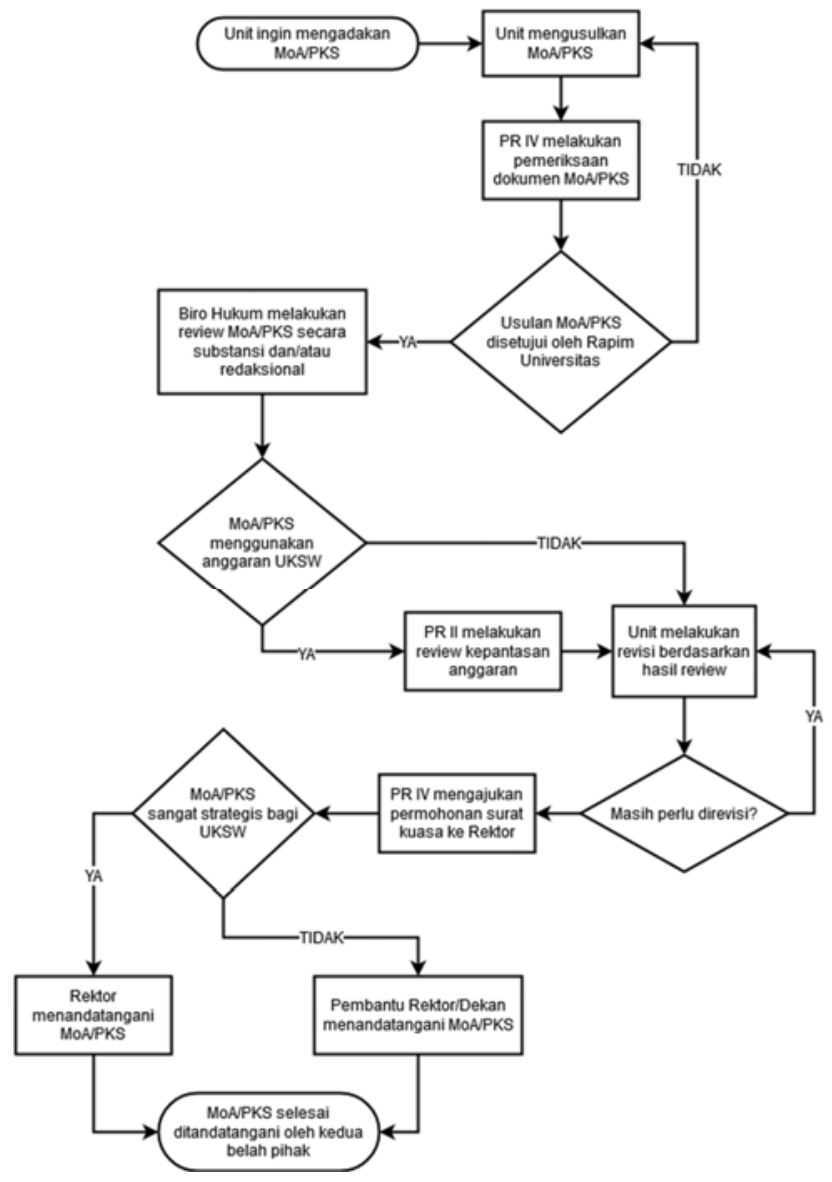

Gambar 2 SOP Usulan MoA/PKS

Gambar 2 menunjukkan SOP usulan Memorandum of Agreement (MoA) yang ditetapkan dalam dokumen Prosedur PR IV-001 Tahun 2018 tentang Usulan Perjanjian Kerja Sama (PKS) dari unit. Unit pengusul bertindak sebagai operator mengajukan usulan Perjanjian Kerjasama (PKS). Pembantu Rektor IV bertindak sebagai validator yang memeriksa kelayakan dokumen usulan kerjasama yang diajukan unit. Apabila dokumen kerjasama tersebut dinyatakan layak untuk ditindaklanjuti, usulan MoA/PKS akan dibawa ke Rapat Pimpinan Universitas untuk dibahas lebih lanjut.Biro Hukum akan menelaah substansi dan redaksional dokumen usulan perjanjian kerjasama yang telah disetujui oleh Rapat Pimpinan Universitas. Keterlibatan Pembantu Rektor II dalam usulan kerjasama ini adalah untuk memastikan kelayakan anggaran yang akan dipergunakan dalam kegiatan yang tertuang dalam dokumen usulan kerjasama. Apabila syarat-syarat adminsitrasi dan legal telah dipenuhi, yang ditunjukkan dengan telah ditandatanganinya dokumen perjanjian kerjasama oleh pihak UKSW dan pihak mitra, dokumen kerjasama diunggah dan diarsipkan dalam sistem informasi kerjasama yang dikembangkan ini. 


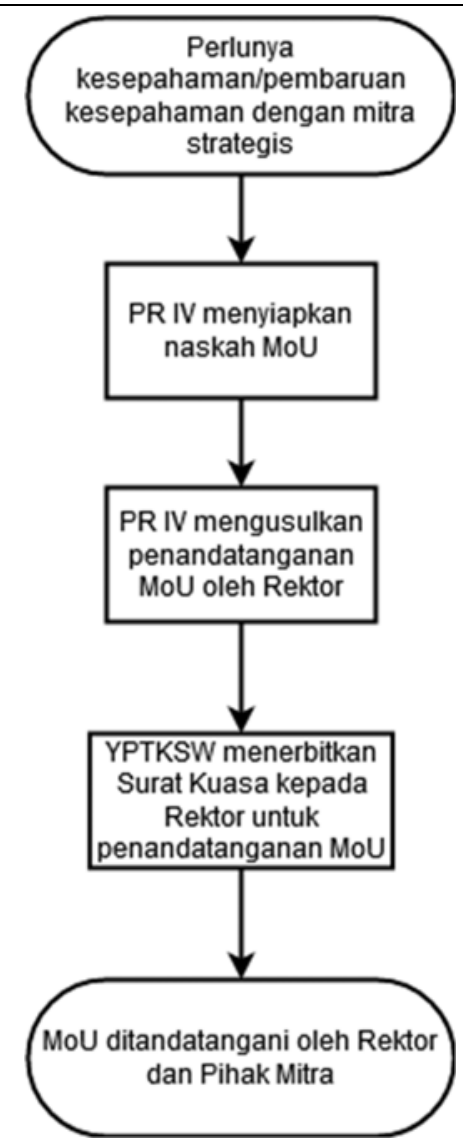

Gambar 3 SOP usulan MoU

Gambar 3 merupakan SOP usulan MoU yang ditetapkan dalam dokumen Prosedur PR IV-002 Tahun 2018 tentang Usulan Memorandum of Understanding $(\mathrm{MoU})$ dari unit. Secara umum, SOP usulan MoU merupakan pengembangan dari usulan MoA, di mana untuk usulan MoU, setelah melalui proses review dari Biro Hukum, Pimpinan UKSW melalui PR IV menyerahkan draft naskah MoU kepada Yayasan Perguruan Tinggi Kristen Satya Wacana (YPTKSW) untuk mendapat persetujuan. Persetujuan dari YPTKSW diwujudkan dalam bentuk Surat Kuasa kepada Rektor untuk menandatangani MoU dengan pihak mitra.

Mengacu pada SOP yang ada, terdapat 5 peran (role) dalam sistem infromasi kerjasama ini yaitu: operator, validator, reviewer, monitoring and evaluation dan administrator. Use case diagram yang diterapkan dalam sistem informasi kerjasama ini ditunjukkan pada Gambar 4. 


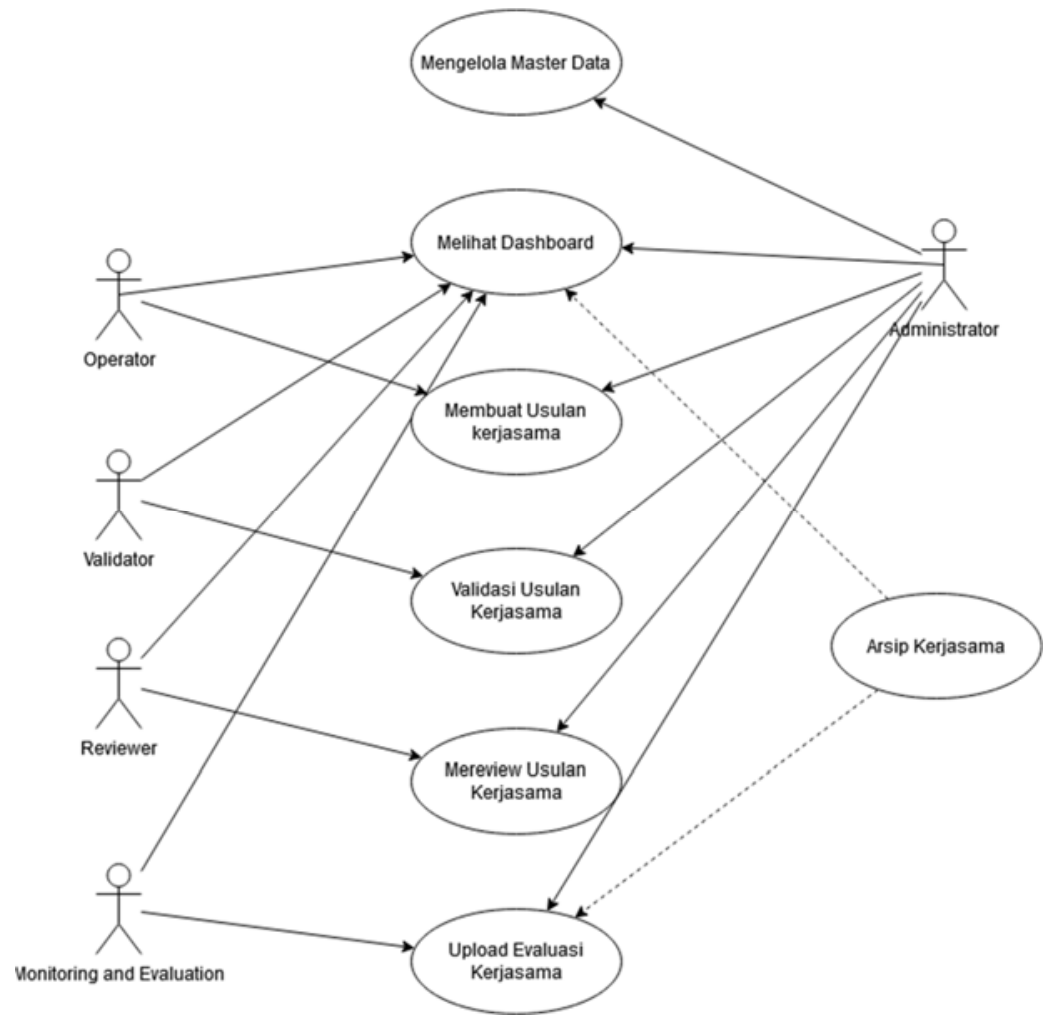

Gambar 4 Use Case Sistem Informasi Kerjasama

\section{Hasil dan Pembahasan}

Sistem informasi kerjasama dikembangkan dengan menggunakan framework CodeIgniter. Pemilihan framework CodeIgniter didasari pada kemudahan yang diperoleh dalam penulisan kode program. Pengembangan sistem informasi kerjasama menerapkan konsep Hierarchical Model-View-Controller (HMVC) yang membagi model, view dan controller ke dalam masing-masing direktori berdasarkan modul-modul yang dibuat. Penerapan konsep HMVC sangat memudahkan pengelolaan sistem atau aplikasi yang terdiri dari banyak modul [11].

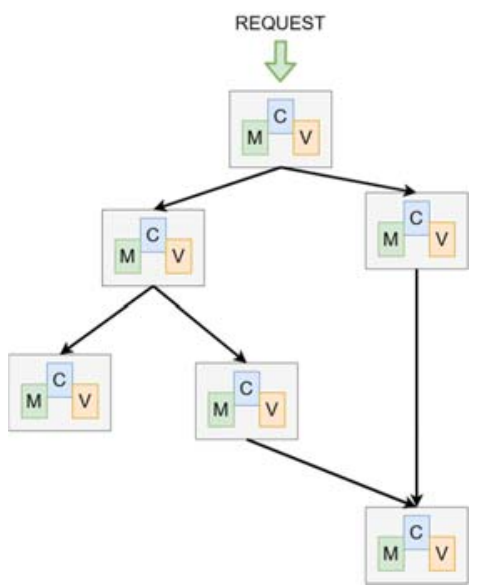

Gambar 5 Hierarchical Model-View-Controller Pattern 
AITI: Jurnal Teknologi Informasi

Volume 17 No. 2 Agustus 2020, 86-103

Seperti yang terlihat pada Gambar 5, konsep HMVC merupakan pengembangan dari konsep Model-View-Controller (MVC) di mana setiap modul dapat memiliki Model-View-Controller-nya masing-masing. Setiap modul juga dapat memiliki 1 atau lebih sub-modul yang juga dapat memiliki MVC-nya masingmasing.

Struktur direktori aplikasi dibuat dengan memisahkan direktori yang dapat diakses langsung dari web dengan direktori yang hanya dapat diakses oleh script program. Pemisahan ini bertujuan untuk mencegah akses langsung oleh publik terhadap direktori-direktori tertentu atau dokumen-dokumen penting yang tersimpan di dalam sistem. Struktur direktori aplikasi ditunjukkan pada Gambar 6 .

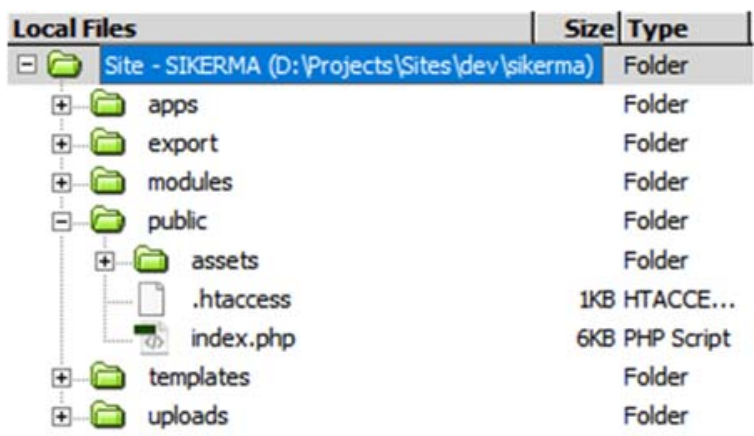

Gambar 6 Struktur direktori aplikasi

Database dibuat menggunakan PostgreSQL, yang merupakan salah satu Relational Database Management System (RDBMS) open source yang memiliki fitur sangat lengkap sehingga cocok digunakan untuk sistem basis data berskala menengah dan besar[12]. Hasil perancangan struktur database terdapat pada Gambar 7.

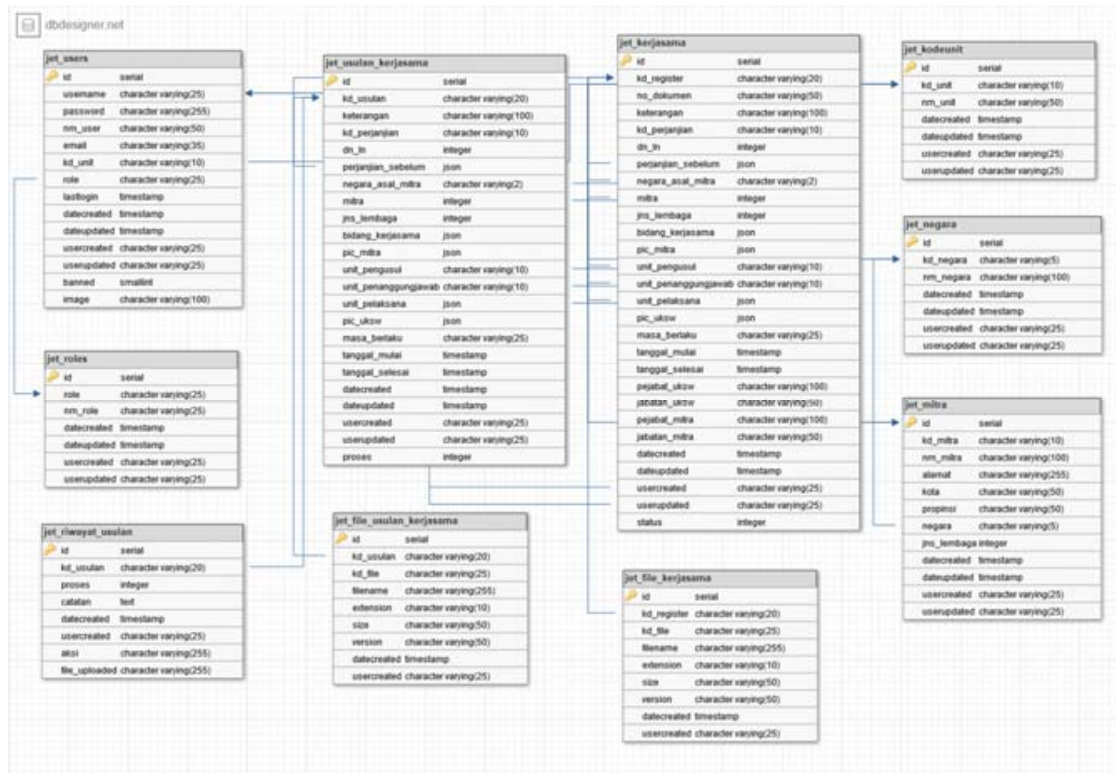

Gambar 7 Rancangan database 
Sistem informasi kerjasama yang dikembangkan ini menerapkan sistem otentikasi pengguna sebagai fungsi dasar sistem keamanan sistem. Dengan sistem otentikasi ini, hanya pengguna yang memiliki hak akses dengan peran tertentu yang diberikan ijin untuk masuk dan mengelola arsip perjanjian kerjasama. Pengguna diminta untuk memasukkan username dan password untuk dapat mengakses modul-modul yang terdapat di dalam Sistem Informasi Kerjasama ini, seperti yang ditunjukkan pada Gambar 8.

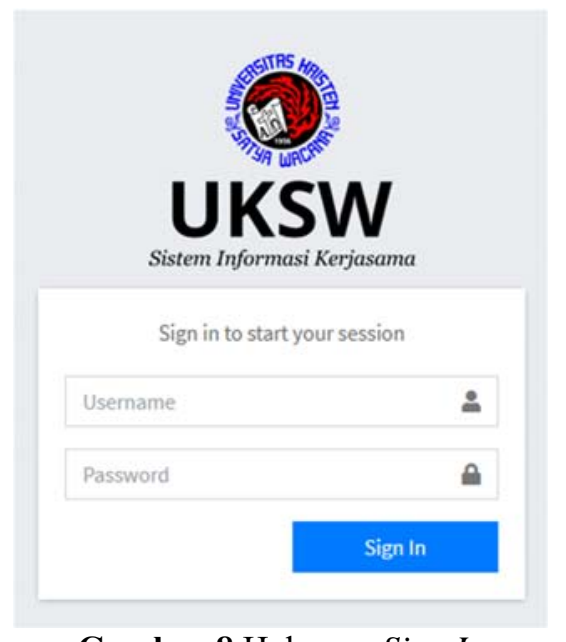

Gambar 8 Halaman Sign In

Perlindungan sandi pengguna dilakukan dengan menggunakan fungsi hash pada password, menggunakan hash algorithm SHA512. Sandi yang di-hash merupakan penggabungan dari hasil hash menggunakan algoritma SHA1 pada sandi yang sebenarnya (plain text password), dengan nilai dari variabel auth_key yang telah ditentukan. Proses hash password pengguna ditunjukkan pada Kode Program 1.

Kode Program 1 Password Hash dan Validasi

1. public function auth()\{

2. if (\$this->input->is_ajax_request() \&\& \$_POST) \{

3. \$this->form_validation->set_rules('username', 'Username', 'trim|required| callback_check_username');

4. \$this->form_validation->set_rules('password', 'Password', 'trim|required|sha1| callback_check_password');

5. $\ldots$

6. $\}$ \}

7. protected function get_hash(\$string, $\$$ mode $=$ 'password' $)\{$

8. \$this->load->config('auth');

9. if(is_array (\$string) $)\{$

10. \$string = implode(' ', \$string);

11. \}

12. return hash('sha512', \$this->config->item('auth_'.\$mode.'_hash_key'). \$string);

13. \}

14. function_check_password(\$str) \{

15. \$username $=\$$ this - $>$ input $->$ post ('username' $)$;

16. \$password=\$this->get_hash(\$str, 'password');

17. \$where=['username ' $=>$ \$username, ' password' $=>\$$ password] ;

18. ...

19. if ( (int) \$query->num_rows ()$===1)\{$ 
AITI: Jurnal Teknologi Informasi

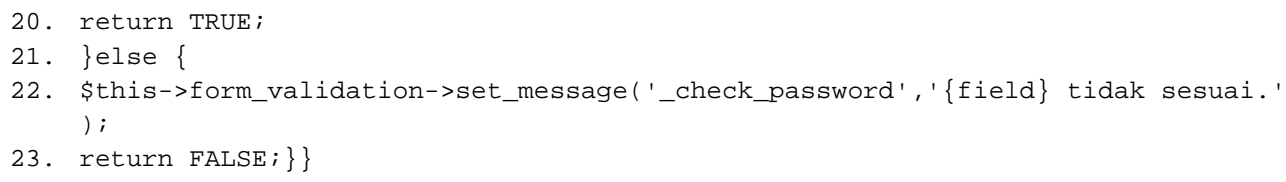

Pengguna yang telah melewati tahap otentikasi, akan dialihkan menuju halaman Dashboard, di mana terdapat ringkasan informasi perjanjian kerjasama yang tersimpan dalam basis data Sistem Informasi Kerjasama seperti yang terdapat pada Gambar 9. Menu-menu yang tersedia disesuaikan dengan peran yang dimiliki oleh setiap pengguna. Pengaturan menu ditunjukkan pada Kode Program 2.

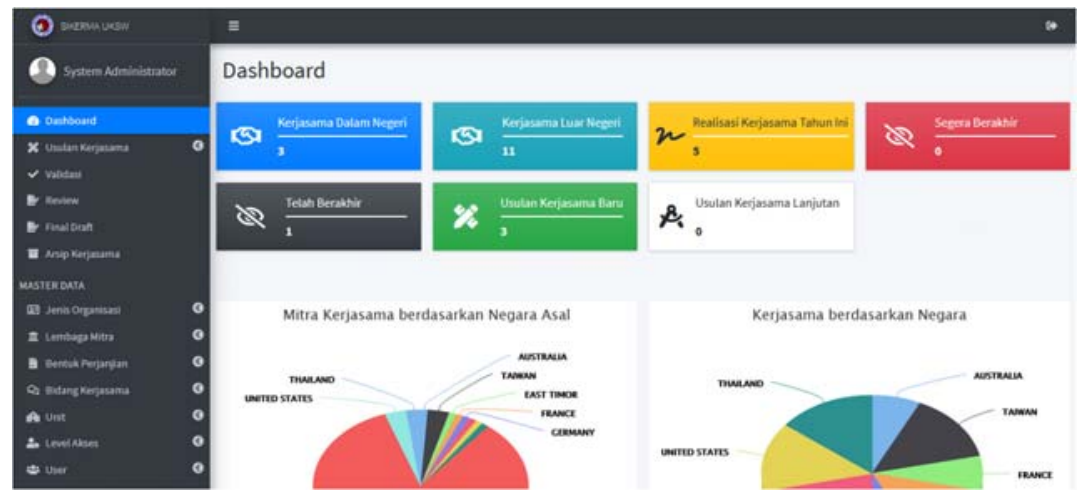

Gambar 9 Tampilan halaman dashboard Administrator

Kode Program 2 Pengaturan Menu berdasarkan Role

1. private function navmenu( $)\{$

2. \$out $='<u l$ class="nav nav-pills nav-sidebar text-sm nav-compact nav-flat flex-column" data-widget="treeview" role="menu" data-accordion="false">

3. <li class="nav-item" $>$ ' anchor ('','<i class="nav-icon fas fa-tachometer alt" $></ i><$ p $>$ Dashboard $</ p>$ ', ['class' => 'nav-link' . ( (\$this->uri->segment $(1)==1$ ' || \$this->uri->segment(1)=='home')?' active':'')]). '</li>

4. '. $\left(\left(\$\right.\right.$ this $->$ role $==$ 'administrator' || this $->$ role $==$ 'validator $\left.{ }^{\prime}\right)$ ?' $<$ li class="nav-item" $>$ ' anchor ('validasi', '<i class="nav-icon fas facheck" $></ i><p>$ Validasi</p $>$ ', [ 'class'=>'nav-link' . (\$this->uri->segment $(1)==$ 'validasi'?' active':'')]).'</li>':'').'

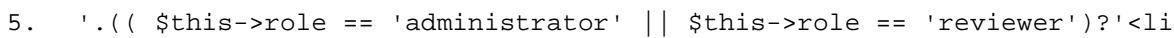
class="nav-item" $>$ '. anchor ('review', '<i class="nav-icon fas fa-filesignature" $></$ i $><$ p $>$ Review $</ p>$ ', ['class' '=> nav-link' . (\$this->uri->segment $(1)==$ 'review'?' active':'')]).'</li>':'').'

6. '. (( \$this $->$ role == 'administrator' || this $->$ role $==$ 'pengusul' $)$ ?' $<$ li class="nav-item" $>$ '. anchor('drafting', '<i class="nav-icon fas fa-filesignature" $></ i><p>$ Final Draft $</ p>1,[$ ['class'=>'nav-link' . (\$this->urisegment $(1)==$ 'drafting' ? ' active':'')]). '</li $>$ ':'').'

7. $<$ li class="nav-item" $>$ ' anchor ('kerjasama', '<i class="nav-icon fas faarchive" $></ i><$ p $>$ Arsip Kerjasama</p $>$ ', ['class'=>'nav-link' . (\$this->uri$>$ segment $(1)==$ 'kerjasama'?' active':'')]).'</li $>$

8. </ul>';

9. return \$out;

Selain melalui menu, kontrol akses pengguna juga diterapkan pada setiap controller dan beberapa bagian dalam view. Tujuan dari pengaturan ini adalah untuk mencegah akses oleh pengguna yang tidak memiliki peran yang sesuai ke dalam controller, dengan cara memasukkan URL secara langsung. 
Kode Program 3 Kontrol Akses pengguna di Controller

1. class Usulan extends Main_Controller \{

2. public function _construct() \{

3. parent: :_construct ();

4. \$allowedRoles=['administrator', 'pengusul'];

5. if(! in_array (\$this->role, \$allowedRoles $))\{$

6. Show_error('Access to current page forbidden for current role', 403, \$heading=' 403 Access Forbidden');

7. $\}\}$

8. ...

9. $\}$

Penempatan perintah kontrol akses di dalam fungsi konstruktor seperti yang terdapat pada

Kode Program 3 bertujuan agar seluruh fungsi publik yang terdapat dalam kelas ini hanya dapat diakses oleh pengguna yang memiliki peran seperti yang telah ditentukan pada baris ke-4

Kode Program 3. Akses oleh pengguna dengan peran selain yang telah ditentukan, akan menampilkan pesan kesalahan seperti yang terdapat pada Gambar 10 .

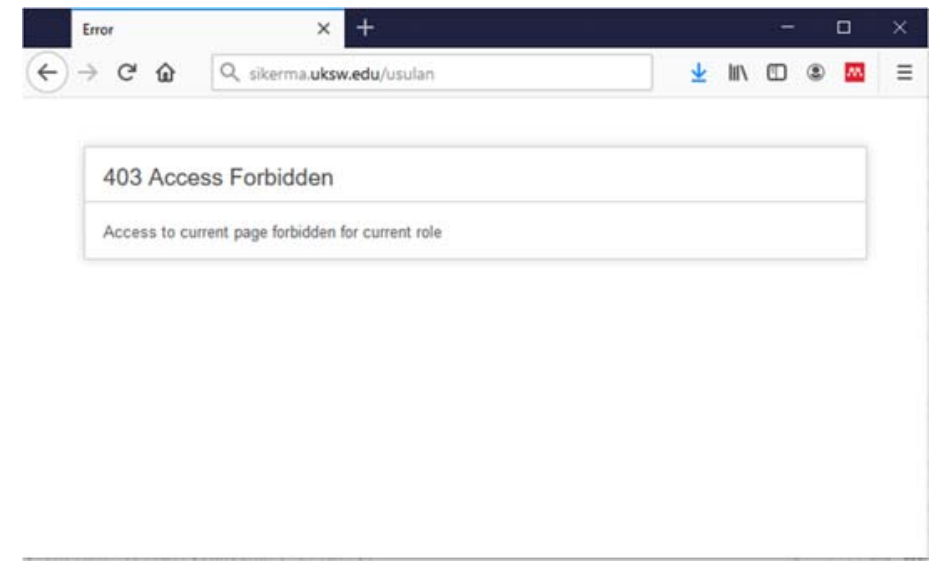

Gambar 10 Tampilan halaman Access Forbidden

Gambar 11 menunjukkan tampilan halaman form usulan kerjasama. Usulan kerjasama dapat diajukan oleh pengguna Fakultas/Unit yang memiliki peran "pengusul".

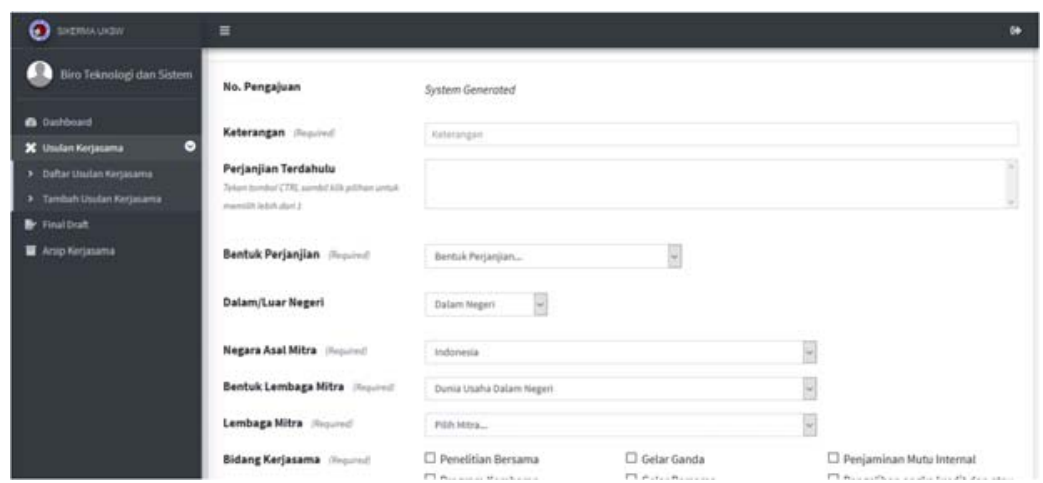

Gambar 11 Halaman Form Usulan Kerjasama 
Kode Program 4 Proses Simpan Usulan Kerjasama

1. public function save()\{

2. if (\$this->input->post() \&\& \$this->input->is_ajax_request()) \{

3. ...

4. \$recdata=array ( 'keterangan' $=>\$$ keterangan, 'kd_perjanjian' $=>\$ k d \_p e r j a n j i a n, ' d n \_l$ $\mathrm{n}^{\prime}=>\$ d n \_l n, '$ perjanjian_sebelum ' =>\$perjanjian_terdahulu, 'negara_asal_mitra' $=>\$ n$ egara_asal_mitra,' 'mitra' $=>$ \$mitra, 'jns_lembaga' $=>$ \$ jns_lembaga, 'bidang_kerjasama '=>\$bid_kerjasama, ' pic_mitra'=>\$pic_external, 'unit_pengusul' =>\$unit_pengusul, ' unit_penanggungjawab ' =>\$unit_penanggungjawab, ' unit_pelaksana ' =>\$unit_pelaks, ' $p$ ic_uksw' =>\$pic_internal, 'masa_berlaku'=>\$masa_berlaku, 'tanggal_mulai ' $=>$ \$tangga 1_mulai, ' tanggal_selesai' =>\$tanggal_selesai);

5. if (\$this->input->post ('update', TRUE) \&\& (bool) \$this->input$>$ post ( 'update', TRUE $)===$ TRUE $)\{$

6. \$update=TRUE;

7. \$id=\$this - >input - >post ( ' id', TRUE);

8. \$kd_usulan=\$this - >input ->post ('kd_usulan' ',TRUE);

9. \$where $=\left[\right.$ 'id' $^{\prime}=>$ \$id, ' kd_usulan' $=>\$$ kd_usulan] ;

10. \$proses=\$this->get_current_proses(\$id,\$kd_usulan);

11. \$aksi='Mengubah Usulan Kerjasama dengan Kode: '.\$kd_usulan;

12. \} else \{

13. \$update=FALSE;

14. \$kd_usulan=\$this ->gen_kd_usulan(\$kd_perjanjian);

15. \$proses=0;

16. \$aksi='Membuat Usulan Kerjasama Baru dengan Kode: '. \$kd_usulan;

17. \}

18. \$this->recs->transBegin( );

19. if (\$update===TRUE) \{

20. \$this->recs->setRecords('jet_usulan_kerjasama', \$recdata, 'update', \$where);

21. $\}$ else \{

22. \$this->recs->setRecords('jet_usulan_kerjasama', \$recdata, 'insert' );

23. \$this->recs-

24. $\}$

$>$ setRecords('jet_kd_register', array( 'kd_register'=>\$kd_usulan), 'insert') ;

25. . .

26. \}\}

Cuplikan struktur kode yang terdapat pada

Kode Program 4 merupakan fungsi yang dijalankan pada proses menyimpan usulan kerjasama, baik untuk usulan baru maupun perubahan dari usulan yang telah diajukan sebelumnya. Variabel \$update digunakan sebagai penanda untuk membedakan proses memasukkan usulan baru atau memperbarui usulan.

Beberapa data disimpan dalam format Javascript Object Notation (JSON) dengan tujuan untuk menyederhanakan penggunaan kolom. Format JSON digunakan untuk menyimpan data sejenis yang jumlahnya tidak tetap atau bervariasi dalam setiap perjanjian kerjasama, seperti data perjanjian terdahulu, bidang kerjasama, unit pelaksana, dan PIC baik internal maupun eksternal. Dengan demikian, tidak diperlukan penambahan kolom maupun tabel relasi jika terjadi penambahan jumlah data[13].

Direktori penyimpanan berkas usulan kerjasama yang diunggah, ditempatkan di luar direktori yang dapat diakses publik. Path direktori ini dituliskan relatif terhadap web root Sistem Informasi kerjasama seperti yang terdapat pada 
Kode Program 5. Tujuannya adalah untuk mencegah berkas-berkas tersebut dapat diakses oleh pihak-pihak yang tidak berkepentingan secara langsung. Akses berkas hanya dapat dilakukan melalui script yang disediakan di dalam sistem, seperti yang ditunjukkan pada Kode Program 6.

Kode Program 5 Struktur Program Upload Berkas

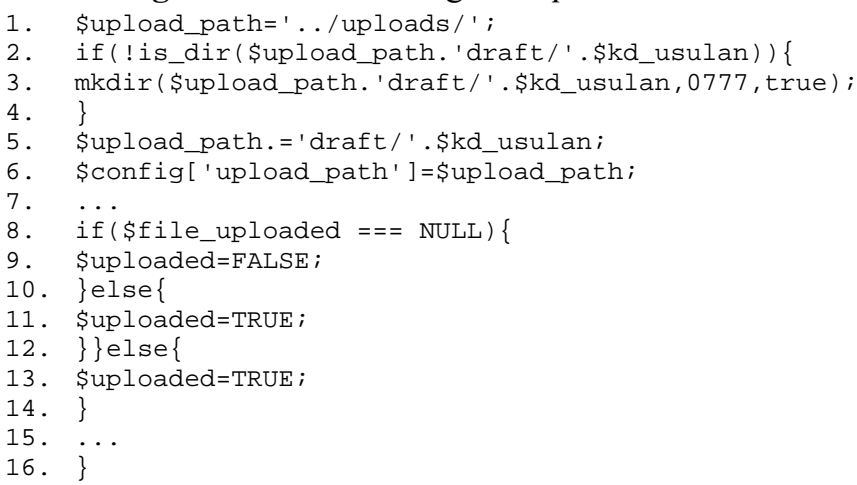

Kode Program 6 Struktur program download berkas

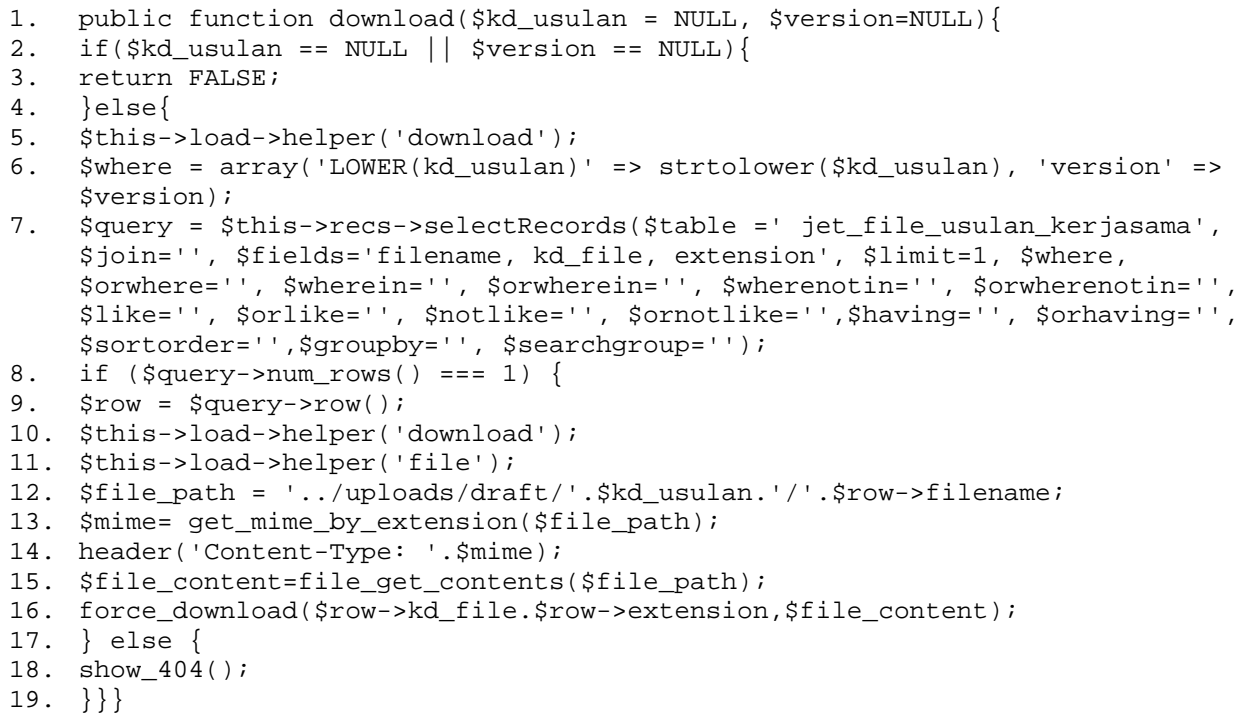

Daftar usulan kerjasama yang diajukan oleh unit pengusul ditunjukkan pada Gambar 12. Unit pengusul diperkenankan untuk mengubah atau memperbaiki usulan kerjasama yang diajukan, apabila usulan kerjasama berstatus draft atau dikembalikan untuk diperbaiki baik oleh validator, reviewer, atau administrator. Usulan yang tidak berstatus draft atau dikembalikan/ditolak, tombol edit dan delete tidak aktif, demikian sebaliknya tombol akan aktif apabila usulan kerjasama berstatus draft atau dikembalikan/ditolak. 
AITI: Jurnal Teknologi Informasi

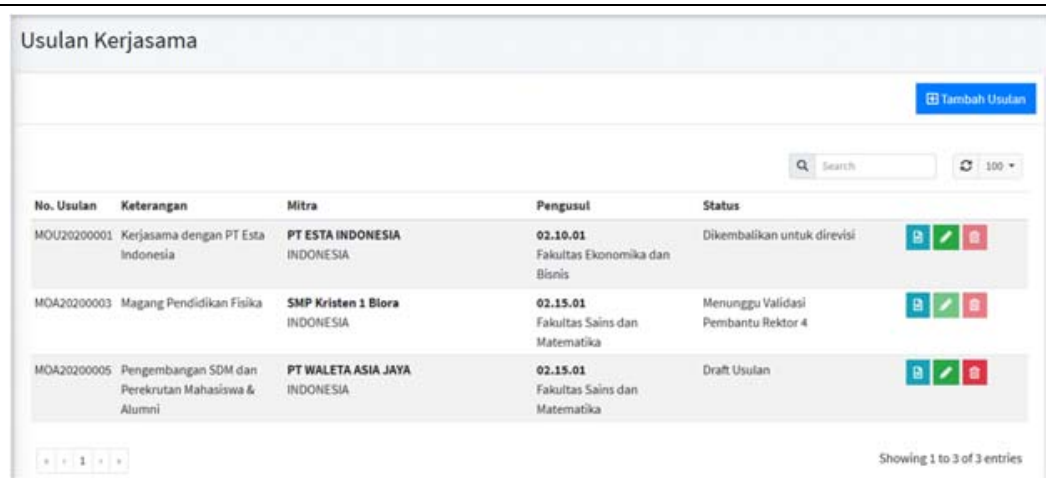

Gambar 12 Daftar Usulan Kerjasama

Usulan yang telah diajukan unit pengusul akan memasuki tahap validasi, dan review. Validator dan reviewer dapat memberikan komentar terkait usulan kerjasama, serta mengubah status usulan tersebut sesuai dengan tahapan yang sedang dikerjakan. Perubahan status usulan yang dilakukan oleh validator dan reviewer dapat berupa "disetujui dan diteruskan ke tahap selanjutnya" atau “dikembalikan kepada unit pengusul untuk diperbaiki". Unit pengusul dapat memantau perkembangan usulan kerjasama yang diajukan melalui fitur riwayat usulan yang terdapat pada detail usulan, seperti yang ditunjukkan pada Gambar 13.

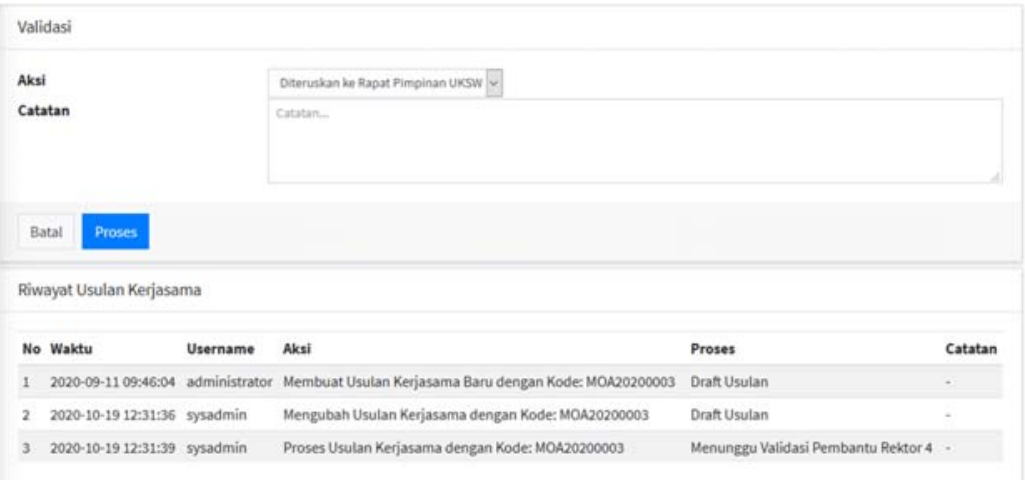

Gambar 13 Proses Validasi dan Riwayat Usulan Kerjasama

Untuk menyederhanakan sistem yang dibangun, proses validasi hingga penyusunan draft akhir menggunakan form dan kode yang sama. Setiap tahapan proses dibedakan berdasarkan status dari masing-masing usulan, seperti yang ditunjukkan pada Kode Program 7.

Kode Program 7 Struktur program validasi usulan

1. public function detail() \{

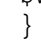




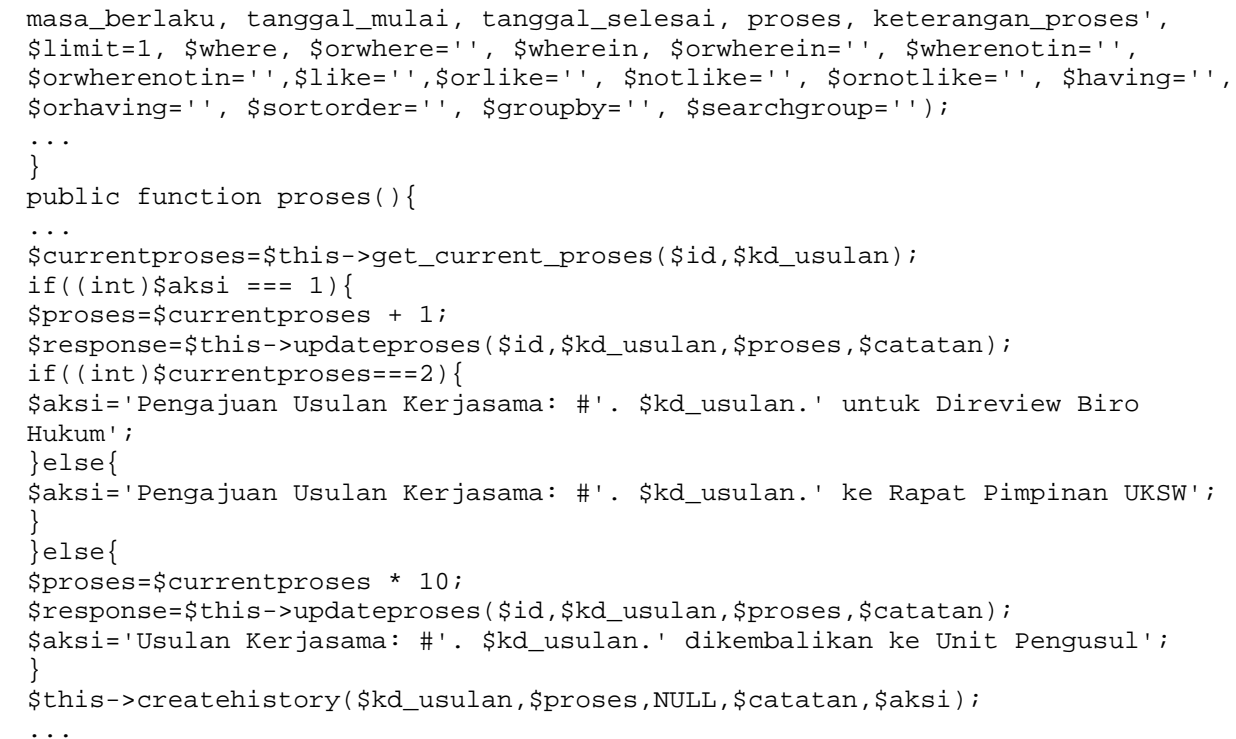

Perjanjian kerjasama yang telah disetujui dan ditandatangani oleh pihak UKSW dan mitra, akan dimasukkan ke dalam arsip kerjasama seperti yang terdapat pada Gambar 14. Arsip kerjasama dibagi ke dalam 3 kategori yaitu perjanjian kerjasama yang sedang berjalan, perjanjian yang telah berakhir dan perjanjian kerjasama yang akan segera berakhir. Perjanjian kerjasama yang masuk dalam kategori segera berakhir adalah perjanjian kerjasama yang akan berakhir dalam kurun waktu kurang dari 3 bulan.

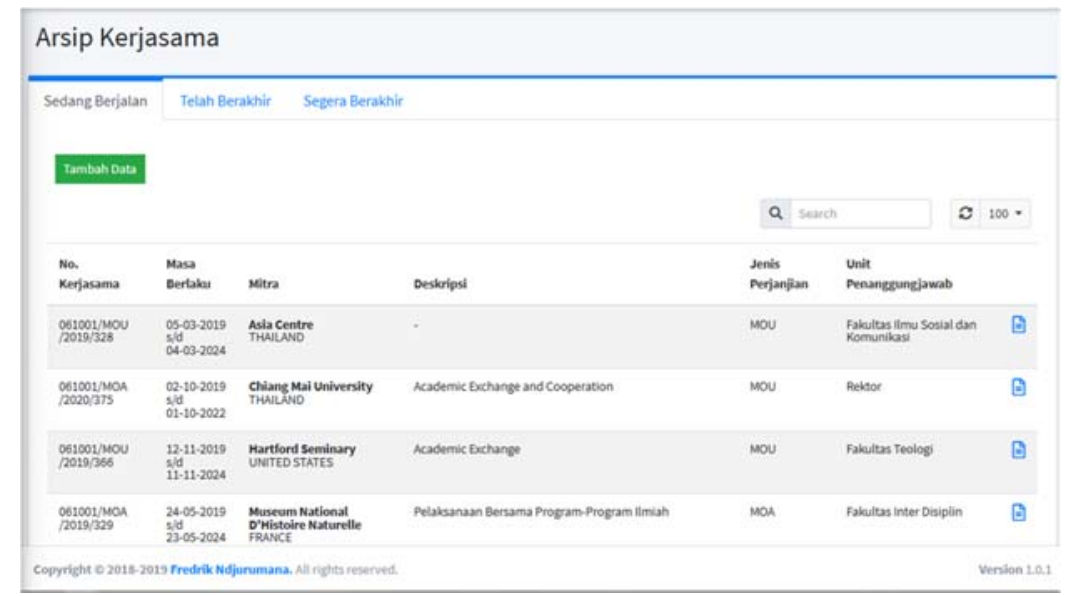

Gambar 14 Arsip Kerjasama

Setelah tahapan pengembangan sistem selesai, perlu dilakukan pengujian untuk membuktikan bahwa sistem telah sesuai dengan kebutuhan dan harapan pengguna. Pengujian sistem menggunakan metode pengujian blackbox untuk menguji keseluruhan fungsi dan fitur yang terdapat dalam sistem. Pengujian ini bertujuan untuk memastikan tidak ada kesalahan ataupun bug di dalam sistem, dan seluruh modul proses telah berfungsi seperti yang diharapkan. 
AITI: Jurnal Teknologi Informasi

Blackbox merupakan metode pengujian yang mudah digunakan dan berfokus pada aspek fungsionalitas perangkat lunak. Untuk melakukan pengujian dengan metode blackbox, penguji perlu menetapkan sekumpulan kondisi masukan untuk dapat menemukan ada tidaknya kesalahan fungsi, kesalahan antarmuka, kesalahan struktur dan akses basis data, performansi, serta inisialisasi dan terminasi[14]. Hasil pengujian dengan metode blackbox ditunjukkan pada Tabel 1.

Tabel 1 Hasil Pengujian Blackbox

\begin{tabular}{|c|c|c|c|c|}
\hline $\begin{array}{c}\text { Fungsi yang } \\
\text { diuji }\end{array}$ & Situasi Uji & $\begin{array}{l}\text { Output yang } \\
\text { diharapkan }\end{array}$ & $\begin{array}{l}\text { Output yang } \\
\text { diperoleh }\end{array}$ & Hasil \\
\hline Login & $\begin{array}{l}\text { Mengisi form dengan } \\
\text { username dan }\end{array}$ & Gagal Login & Gagal Login & Valid \\
\hline $\begin{array}{l}\text { Input usulan } \\
\text { kerjasama }\end{array}$ & $\begin{array}{l}\text { password yang salah } \\
\text { Form diisi dengan } \\
\text { benar dan lengkap }\end{array}$ & $\begin{array}{l}\text { Sukses } \\
\text { menambah } \\
\text { usulan } \\
\text { kerjasama }\end{array}$ & $\begin{array}{l}\text { Sukses menambah } \\
\text { usulan kerjasama }\end{array}$ & Valid \\
\hline $\begin{array}{l}\text { Ubah usulan } \\
\text { kerjasama }\end{array}$ & $\begin{array}{lr}\text { Mengubah } & \text { usulan } \\
\text { kerjasama } & \text { yang } \\
\text { berstatus draft atau } \\
\text { dikembalikan }\end{array}$ & $\begin{array}{l}\text { Sukses } \\
\text { mengubah } \\
\text { usulan } \\
\text { kerjasama }\end{array}$ & $\begin{array}{l}\text { Usulan kerjasama } \\
\text { berhasil } \\
\text { diperbarui }\end{array}$ & Valid \\
\hline $\begin{array}{l}\text { Ubah usulan } \\
\text { kerjasama }\end{array}$ & $\begin{array}{l}\text { Mengubah usulan } \\
\text { kerjasama yang sedang } \\
\text { diproses }\end{array}$ & $\begin{array}{l}\text { Gagal } \\
\text { mengubah } \\
\text { usulan } \\
\text { kerjasama }\end{array}$ & $\begin{array}{l}\text { Usulan kerjasama } \\
\text { gagal diperbarui }\end{array}$ & Valid \\
\hline $\begin{array}{l}\text { Validasi usulan } \\
\text { kerjasama }\end{array}$ & $\begin{array}{l}\text { Melakukan validasi } \\
\text { usulan kerjasama } \\
\text { dengan opsi menolak } \\
\text { atau menerima }\end{array}$ & $\begin{array}{l}\text { Sukses validasi } \\
\text { usulan } \\
\text { kerjasama }\end{array}$ & $\begin{array}{l}\text { Usulan kerjasama } \\
\text { berhasil divalidasi }\end{array}$ & Valid \\
\hline $\begin{array}{l}\text { Validasi usulan } \\
\text { kerjasama }\end{array}$ & $\begin{array}{l}\text { Pengguna dengan } \\
\text { peran pengusul dan } \\
\text { reviewer membuka } \\
\text { halaman validasi }\end{array}$ & $\begin{array}{l}\text { Halaman } \\
\text { validasi tidak } \\
\text { dapat diakses }\end{array}$ & Akses ditolak & Valid \\
\hline $\begin{array}{l}\text { Review usulan } \\
\text { kerjasama }\end{array}$ & $\begin{array}{lr}\text { Memasukkan } & \text { hasil } \\
\text { review } & \text { usulan } \\
\text { kerjasama } & \end{array}$ & $\begin{array}{l}\text { Sukses review } \\
\text { usulan } \\
\text { kerjasama }\end{array}$ & $\begin{array}{l}\text { Usulan kerjasama } \\
\text { berhasil di-review }\end{array}$ & Valid \\
\hline $\begin{array}{l}\text { Review usulan } \\
\text { kerjasama }\end{array}$ & $\begin{array}{l}\text { Pengguna dengan } \\
\text { peran pengusul dan } \\
\text { validator membuka } \\
\text { halaman review }\end{array}$ & $\begin{array}{l}\text { Halaman } \\
\text { review tidak } \\
\text { dapat diakses }\end{array}$ & Akses ditolak & Valid \\
\hline $\begin{array}{l}\text { Arsip } \\
\text { Kerjasama }\end{array}$ & $\begin{array}{l}\text { Menampilkan arsip } \\
\text { kerjasama berdasarkan } \\
\text { kategori }\end{array}$ & $\begin{array}{l}\text { Arsip } \\
\text { kerjasama } \\
\text { tampil sesuai } \\
\text { kategori }\end{array}$ & $\begin{array}{l}\text { Arsip kerjasama } \\
\text { ditampilkan } \\
\text { sesuai kategori } \\
\text { yang ditentukan }\end{array}$ & Valid \\
\hline
\end{tabular}




\begin{tabular}{llllll}
\hline $\begin{array}{c}\text { Fungsi yang } \\
\text { diuji }\end{array}$ & \multicolumn{1}{c}{ Situasi Uji } & $\begin{array}{l}\text { Output yang } \\
\text { diharapkan }\end{array}$ & $\begin{array}{l}\text { Output yang } \\
\text { diperoleh }\end{array}$ & Hasil \\
\hline $\begin{array}{l}\text { Akses } \\
\text { dokumen }\end{array}$ & $\begin{array}{l}\text { Mengakses dokumen } \\
\text { melalui tautan di } \\
\text { dalam sistem }\end{array}$ & $\begin{array}{l}\text { Dokumen } \\
\text { dapat diunduh }\end{array}$ & $\begin{array}{l}\text { Dokumen dapat } \\
\text { diunduh }\end{array}$ & Valid \\
Akses & $\begin{array}{l}\text { Mengakses dokumen } \\
\text { tonpa otentikasi }\end{array}$ & $\begin{array}{l}\text { Dokumen } \\
\text { tidak dapat } \\
\text { diunduh }\end{array}$ & $\begin{array}{l}\text { Dokumen tidak } \\
\text { ditemukan }\end{array}$ & Valid \\
& & & & & \\
\hline
\end{tabular}

Hasil pengujian menunjukkan bahwa fungsi-fungsi yang dibuat dalam sistem ini telah berjalan dengan baik. Penerapan hak akses berdasarkan peran yang diterapkan dalam sistem ini juga dapat berjalan dengan baik. Hasil yang diperoleh dari pengujian ini sesuai dengan rancangan sistem, yang menentukan batasan akses berdasarkan peran yang dimiliki masing-masing pengguna. Sistem ini juga telah menerapkan perlindungan terhadap dokumen-dokumen perjanjian kerjasama, di mana hanya pengguna yang memiliki peran yang sesuai yang dapat mengakses dokumen-dokumen perjanjian kerjasama.

\section{Simpulan}

Sistem informasi kerjasama yang dikembangkan, telah berfungsi dengan baik untuk mengarsipkan dokumen-dokumen perjanjian kerjasama yang telah dilakukan UKSW. Sistem ini juga telah berfungsi dengan baik untuk mengelola usulan-usulan kerjasama yang diajukan oleh Fakultas dan Biro yang ada di UKSW. Fakultas dan Biro dapat mengetahui perkembangan tindak lanjut usulan kerjasama yang diajukan kepada Pimpinan UKSW, dan dapat melakukan perbaikan-perbaikan terhadap draft naskah perjanjian kerjasama baik dari segi aspek hukum maupun anggaran berdasarkan catatan-catatan yang diberikan oleh reviewer. Dengan adanya sistem ini, UKSW dapat mengelola arsip-arsip perjanjian kerjasama dengan lebih baik. Saran pengembangan sistem ini adalah untuk mengintegrasikan sistem informasi kerjasama ini dengan SSO dan sistem-sistem yang telah ada di UKSW sebelumnya untuk menghasilkan suatu sistem yang terintegrasi.

\section{Daftar Pustaka}

[1] R. Sidik, "Model Sistem Informasi Kolaborasi Pada Kerjasama Antar Universitas (University To University)," J. Teknol. dan Inf., vol. 4, no. 2, pp. 1-10, Sep. 2014.

[2] A. Sugiarto and T. Wahyono, Manajemen Kearsipan Modern (Dari Konvensional ke Basis Komputer). Yogyakarta: Gava Media, 2005.

[3] G. Farell, H. K. Saputra, and I. Novid, "Rancang Bangun Sistem Informasi Pengarsipan Surat Menyurat (Studi Kasus Fakultas Teknik UNP)," JTIP J. Teknol. Inf. dan Pendidik., vol. 11, no. 2, pp. 55-62, Sep. 2018.

[4] W. Welda and B. A. Minartiningtyas, "Sistem Informasi Pengelolaan Kerjasama Bidang Humas pada STMIK STIKOM Indonesia," J. Sisfokom 
(Sistem Inf. dan Komputer), vol. 6, no. 2, p. 86, Sep. 2017.

[5] Kementerian Pendidikan dan Kebudayaan Republik Indonesia, Peraturan Menteri Pendidikan dan Kebudayaan Republik Indonesia Nomor 14 Tahun 2014. Berita Negara Republik Indonesia Tahun 2014 Nomor 253, 2014.

[6] T. Salmin, "SISTEM PENGARSIPAN ARSIP ELEKTRONIK," J. Pustaka Ilm., vol. 4, no. 2, pp. 706-711, Aug. 2019.

[7] A. Sugiarto, Y. B. R Silintowe, and L. N. Kartika, "Pengembangan Sistem Kearsipan Elektronik Berbasis Client-Server," J. Teknol. Informasi-Aiti, vol. 10, no. 1, pp. 46-61, 2013.

[8] R. Rusdiansyah, "Membangun Prototype Sistem Informasi Arsip Elektronik Surat Perjanjian Kerjasama pada Business Support Department," J. Pilar Nusa Mandiri, vol. 14, no. 2, pp. 157-162, Sep. 2018.

[9] C. A. Sugianto and I. Aulia, "Pengembangan Sistem Informasi Kerjasama Berbasis Web Studi Kasus: Pada SEAMOLEC,” J. RESTI (Rekayasa Sist. dan Teknol. Informasi), vol. 1, no. 2, p. 137, Oct. 2017.

[10] R. Naz and M. N. A. Khan, "Rapid applications development techniques: A critical review," vol. 9, pp. 163-176, 2015.

[11] P. Sabnani and V. Bajpai, "A Hierarchical Tree Based Online Web Portal," A Hierarchical Tree Based Online Web Portal, vol. 6, no. 5, pp. 4682-4684, 2015.

[12] A. D. Praba, "Aplikasi Rekap Mengajar Berbasis Webiste Dengan Database PostgreSQL," Indones. J. Netw. Secur., vol. 8, no. 1, pp. 27-31, Feb. 2018.

[13] M. A. Rosid, "Implementasi JSON untuk Minimasi Penggunaan Jumlah Kolom Suatu Tabel Pada Database PostgreSQL," JOINCS (Journal Informatics, Network, Comput. Sci., vol. 1, no. 1, pp. 33-42, Jul. 2016.

[14] M. S. Mustaqbal, R. F. Firdaus, and H. Rahmadi, "PENGUJIAN APLIKASI MENGGUNAKAN BLACK BOX TESTING BOUNDARY VALUE ANALYSIS (STUDI KASUS: APLIKASI PREDIKSI KELULUSAN SMNPTN),” J. Ilm. Teknol. Infomasi Terap., vol. 1, no. 3, 2015. 